\title{
13. WAYS OF LEARNING OF ADULT EDUCATORS IN UNCERTAIN PROFESSIONAL CONTEXTS
}

\section{INTRODUCTION}

Considering that adult education is an educational practice field and simultaneously a field of reflection and research (Canário, 2008; Barbier, 2009), this research focused on a particular category of adult educators, on a field also specific to adult education which is the Recognition of Prior Learning (RPL). Canário (2008) stated that the dissemination of educational practices aimed at adults is accompanied by a process of internal differentiation and complexity of the adult education field itself, which is notable at three levels; firstly on the level of educational practices in terms of purposes, ways and target groups; secondly, in terms of the diversity of the institutions involved; and lastly, in terms of the new concern with the professionalisation of adult educators (Canário, 2008).

In Portugal the concern with adult education increased with the transition to a democracy, which occurred with the revolution on the 25th of April, 1974. Until then, adult education 'as a specific social field had practically no past in Portugal' (Rothes, 2004, p. 62) and training directed at adult educators did not exist. Despite the strengthening of the interest after the democratisation process of the country, adult education has been a field full of discontinuities. As mentioned by Lima (2008), over the past three decades adult education was marked by discontinuous educational policies, characterised by the absence of a plan of continuity. Adult education policies are characterised by discontinuity in the last decades. Similarly adult educators' pathways have been marked by discontinuous patterns. In Portugal, after the end of the 1990s, RPL was launched and integrated with adult education public policies. Due to the New Opportunities Initiative, between 2006 and 2010, there were an increasing number of both adult learners and adult educators involved in RPL. But after 2011, RPL suffered a strong disinvestment by the Government and thus adult education and training policy was suspended. Between 2012 and 2013 all RPL centres were closed. After that, the majority of adult educators involved in RPL became unemployed. After 2014, RPL has been implemented, but involves fewer number of adult educators. Additionally, adult educators involved in adult education provision have been hired and fired according to national programmes underdevelopment or suspended programmes. When programmes are under development, they are positive as adult educators but when programmes are suspended they assume other professional identities. 
Social actors who have dedicated themselves to adult education are thus hostages of the changes in policies in this area. With the emergence of new educational practices in the field of adult education, there have been new actors to perform newly created professional activities. On the one hand, we have adult educators who have moved from other professional activities belonging to the education field and are therefore already familiar with issues related to education. On the other hand, we have adult educators who, for the first time, have or don't have professional experience in other knowledge areas. The design of adult educators' training systems takes into account a broad concept of adult education (Castro, Guimarães, \& Sancho, 2007). Adult educators should be able to act in a wide range of educational activities, and they must be able to achieve different goals, and to work with different target groups and in several educational contexts. Loureiro (2012) highlighted the need to study 'more continuously' (p. 127) the new educational contexts that have been emerging and the actors who are working in this field of practices.

The aim of this chapter is to discuss the ways of learning of adult educators in a changing world. Considering that learning is an activity of knowledge appropriation that one does not possess (Charlot, 2000), but whose existence is in objects, places and people, the current study has the intention of providing input into the adult educators' learning ways in a changing professional context. This chapter focuses on a specific category of adult educators named RPL (Recognition of Prior Learning), professionals who had an important role in the implementation and development of RPL. Firstly, I will discuss how adult educators who had worked in RPL learned to do their job. Secondly, I will discuss how adult educators coped with the uncertainty of their professional pathways in the adult education field.

\section{WAYS OF LEARNING IN ADULT EDUCATION}

Charlot (2000) stated that human beings have an obligation to learn, this duty is conferred with the act of birth. According to the author, learning has the aim of selfforming the individual, in a way that the individual becomes someone, becomes a unique example of someone and becomes a member of a community, sharing its values and occupying a place in it. The individual has the need to learn to live in society 'to appropriate the world' (Charlot, 2000, p. 53). Learning is thus a dual process in which the individual builds himself/herself and is constructed by others, in a dialectical relationship.

In everyday life, humans establish relationships with others, and with the external environment and the social world. When an individual relates with the world, he/she acts over it, producing changes on a physical, mental and social level, giving meaning and assigning meaning to the acts and the environment in which these take place. Barbier (2009) stated that the activity of the individual is both a 'world transformation process and a process of transformation of himself/herself transforming the world' (p. 122). When the individual acts, he/she has a transformative action on the world, a result of the involvement with the physical, social and mental environment. 
Through interactions with others and with the world in general, individuals acquire a set of knowledge, skills and competences that will promote a better individual environment and adjustment, facilitating appropriate answers to the demands of everyday life. Learning that is a result of this interaction may have been produced in formal, non-formal and informal contexts, and may have more or less permanent effects. Learning promotes the construction, by the individual, of a world view, that is, a view of himself/herself, of the relationship with others and the social reality. This world vision becomes concrete in a system of representations that works simultaneously to read the reality on a confirmatory way or as a reference point to build new world views (Canário, 2008).

Experience has received a growing valorisation in adult education, namely in professional life, being seen as a source of learning (Zeitler, Guérin, \& Barbier, 2012). The concepts of experience and learning from experience can have several meanings as Charlier, Roussel, and Boucenna (2013) stated, experience can be cognitive and affective, individual or collective, and refers to the professional or personal life. The concept of experience has two meanings: one characterised by the orientation towards the future, and the other referring to the past (Villers, 1991). In the first sense, experience is linked to an attempt, to the action to test something which the outcome is not totally unknown, existing data that may point out possible outcomes. According to the second meaning, the action has already taken place and it has already been experienced by the individual. In this second formulation, experience is a way by which a person gains knowledge. That is the reason why experience can have learning value.

According to Zeitler, Guérin, and Barbier (2012), experience can designate an activity, the understanding about certain life situations and the process that derives from these situations. Experience is what underlies being an active part of several individual situations in different contexts, and the products that are derived from this process. Bondía (2002) believed that experience is the "possibility that something happens to us or touches us" (p. 24) and requires time to observe, listen, think and reflect. According to this author, the knowledge of experience results from the development "of the sense or the nonsense of what happens to us' (p. 27).

Lived situations are the base of experience (Charlier, Roussel, \& Boucenna, 2013), although they are not an a priori experience. An experience presupposes, on the one hand, a link to a lived situation, and on the other hand a detachment from the situation, which allows the construction of meaning. For an experienced situation to acquire meaning and become significant, it must be thought about by the individual; it has to undergo a reflective process. Reflection allows experienced situations to acquire a meaning for the individual. Experience leads to 'a reconstruction of the meaning' (Charlier, Roussel, \& Boucenna, 2013, p. 11) of lived situations. Canário (2008) pointed out that the assignment of importance to the experience in the learning process assumes that it is seen as an internal process of the individual, functioning as a process of self-development along the life path. 
Kolb, an author who was influenced by Dewey, saw the experience as a source of learning and development (Jarvis, 2006). Kolb (1984) presented experiential learning as a cycle, which consists of four stages: concrete experience, reflective observation, abstract conceptualisation and active experimentation. The concrete experience is the basis for observations and reflections. Reflections are assimilated and transformed into abstract concepts, that is, into thoughts, from which are generated new implications for action. Experiential learning is a process of construction of knowledge that involves a tension between the four ways of learning. This process is represented by a circle or spiral, in which the individual will go through each one of the steps that constitute it - experience, reflection, thinking and action in a continuous process, which would result in a learning situation. Experiential learning is thus a process in which knowledge is created from the transformation of experience.

According to Josso $(1991,2002)$, to have learning value, an experience needs to be reflected on and thought about by the individual, in order to extract knowledge and know-how. Josso (2008) referred to all learning as experiential, insofar as the experience requires reflection about what was experienced by the individual. If learning is not experiential, there is transmission of information, but there is no learning. Learning involves the existence of an awareness process, learning from lived experiences and reflection about them. Learning involves a process of change by the individual in a learning context, of transition from one state to another state of knowledge. Josso (2008) also pointed out that there were 'temporalities in the learning processes' (p. 124), that is, the individual learns according to a certain rhythm which the learning process should respect.

Pineau (1991) stated that experiential learning results from direct contact with the action without the intervention of mediators such as educators, curricula and training programmes, or documentation, and it takes place immediately. In order for an experience to acquire learning value, it must be reflected on. The individual needs to reorganise and reconstruct the elements which compose an experience, to give them a sense, in the light of previous lived situations and the way he/she is projected in the future. Pineau (2009) pointed out that learning can be of three types: self-directed learning (autoformation), hetero-learning (hétéroformation) and eco-learning (écoformation). According to this theory, self-directed learning is the mechanism by which the individual appropriates experiences and interactions from daily life. Hetero-learning is about the learning done with people, watching their behaviours, asking them questions and arguing about work procedures and guidelines. Eco-learning focuses on the learning from contact with the environment and its context. Learning is the result of the interaction between the individual and other people, in professional, social and personal contexts. There is learning that derives from the individual's interaction with others and with the environment, and it also may result from the mobilisation of personal resources, in an attitude of reflection about experiences and the incorporation of the sense of these experiences in life. This interrelation between self, others and 
environment makes the learning process 'an ongoing, dialectic and multiform process' (Pineau, 2009, p. 153).

Experiential learning is based on the assumption that individuals learn through experience along with the premise that they assume an active role as well as having the ability to experience and reflect on the situations and events that occur in their daily life (Cavaco, 2009). Experiential learning valorises the work of individuals, their competences and experiences (Lietard, 2007). Dominicé (1991) pointed out that the formative dimension of experience depends largely on the cultural resources that the individual has, which make it possible to assign a meaning to experiences. For an experience to have learning value, it needs to be thought about and reflected on. Adult learning processes should take place in an environment that promotes critical reflection, which involves a critique of the assumptions on which the individuals' beliefs have been built (Mezirow, 1990). According to Mezirow (2000) learning is understood as the process of using a prior interpretation of an experience or situation 'to construe a new or revised interpretation of the meaning of one's experience as a guide to future action' (p. 5).

Learning from experience is part of a concept of education during life, with a character essentially pedagogic and oriented to the individual (Alheit \& Dausien, 2006). According to these authors, the 'non-formal, informal, non-institutionalised and self-organised aspects of learning' (p. 180) acquire a crucial role in the development of the individual. Learning arises from the individual's experiences, 'episodes of transition and crisis' (Alheit \& Dausien, 2006, p. 190), in formal, non-formal and informal life situations, always linked to the context of a concrete biography.

\section{UNCERTAINTY AS THE ONLY CERTAINTY IN THE PROFESSIONAL FIELD}

During the life course, humans spend a significant amount of time working. The way work has been experienced by individuals as well as the role that it has occupying their lives, has been changing over time. In the early twentieth century, work was generally stable, and a worker could carry out his/her professional activity during the course of working life with the same employer, following the evolution of techniques and progressing towards an increased responsibility and specialisation. At this time, when workers began their professional pathways, they had an employment perspective of staying with the same organisation all their working life (Bauman, 2001).

Due to constant social changes, fast technological innovation and the centrality of the economic dimension in current society, professional pathways have changed, both in terms of their beginnings and endings, and in terms of individuals' trajectories. Although work has been considered a means of 'self-realisation and self-expression, the place of a new-found autonomy' (Méda, 1999, p. 143), it is noteworthy that it currently 'can no longer offer a safe axis around which engage and fix self-definitions, identities and life projects' (Bauman, 2001, p. 160). 
In the last decades, in the Western world, both professional pathways and learning processes have been characterised by several reorientations and reconfigurations (Monbaron, 2009). Workers are protagonists of 'randomly' (Dominicé, 2006, p. 348) biographical pathways, and non-linear life pathways, punctuated by ruptures and transitions.

Nowadays, many life pathways don't have sequential developmental phases anymore, but are pathways reduced to life slices separated from each other, made of contrasts, and changes of direction (Dominicé, 2006). The professional pathways of adults are marked by 'turbulence, flexibility, impermanence' (Dominicé, 2006, p. 11), where the perspective of a stable routine or an expected career gives way to 'coping with a flexible labour market' (p. 17). Flexibility is, as noted by Bauman (2001), 'the slogan of the day' (p. 169), and has become a common term spread in Western society, linked to 'the beginning of the work by short-term contracts or no contracts, positions without pension coverage' (p. 169), in an environment where the only certainty is permanent uncertainty.

Individuals are always in movement, as they move from one professional activity to another, and because of this permanent change they do not develop a sense of belonging, becoming strangers to organisational cultures (Robin, 2009). In this context, the attachment to work has no longer a central role in the formation of professional identity. In a late-modern society characterised by continuous changes, adult educators have faced the lack of firm anchors for their identity (Filander, 2005). If before a key part of identity was anchored in the professional activity performed by the individual, currently identity is no longer exclusively linked to the job, but is also a result of sociocultural skills that individuals mobilise to deal with the diversity and unpredictability of life situations. The self-development is thus a result of the experience of experiencing a wide range of circumstances and contexts of life (Monbaron, 2009).

Similar to what happens in almost all areas of activity, adult educators have been experiencing this turbulence and instability in their professional pathways. Combined with the uncertainty that exists in professional pathways, we must note the lack of continuity existing in Portugal with respect to adult education policies (Lima, 2008). Between 2012 and the beginning of 2013, all RPL Centres (named New Opportunities Centres) were closed by governmental initiative. In the beginning of 2014, new RPL centres were opened with another name (Centres for Qualification and Vocational Teaching). These centres' main aims were to develop RPL processes (basic and secondary school education certification) and to inform and guide young people over 15 years and adults over 18 years about education and training offers. Currently a new change is underway in adult education with the implementation of the Qualify Programme (XXI Governo, 2016). This adult education programme has the aim to relaunch the qualification of adults with low level of schooling and to achieve this purpose the number of RPL centres will be increased.

This chapter intends to answer to the following research questions: How did adult educators learn to work as RPL professionals? How are adult educators coping with the uncertainty of their professional pathways in the adult education field? 


\section{RESEARCH METHODOLOGY}

From a methodological point of view, I used a qualitative approach, as it was considered that this is the kind of research that provides a detailed understanding of the issue to investigate, which can be obtained by speaking directly to people, allowing them to produce a narrative of their life experiences (Creswell, 2007). The research was based on a comprehensive perspective that intended to describe, interpret and analyse critically the learning pathways of adult educators who were working in a changing work context.

The method of data collection used was the biographical interview (Pineau \& Le Grand, 1993). The interview began with the following question: 'How did you become an adult educator?' The use of the biographical interview is linked to the need to understand the unique relationship that individuals have with the social and historic world, and also to study the meaning that they give to their experience (Delory-Momberger, 2012). The biographical interview highlights the individual's point of view in the analysis of the social world and the practical knowledge derived from some life experiences (Demazière, 2008).

Empirical data were collected from 32 adult educators who had worked in RPL in adult education centres called New Opportunities Centres. The interviews were recorded on audio support. As a data analysis technique I used thematic content analysis (Bardin, 1995) focused on the four axis that structure this research: professional activity, ways of learning, professional pathways, and professional identity. For this chapter I focused my analysis on the axis named ways of learning. Interview quotations included in this chapter are followed by an identification of the interviewee; however the names of the interviewees are not their names in order to keep anonymity.

\section{WAYS OF LEARNING IN UNCERTAIN PROFESSIONAL CONTEXTS}

The sample consisted of 32 adult educators aged 24 to $52 ; 27$ females and 5 males. Adult educators had different educational backgrounds. The majority of adult educators held higher education degrees in social and human sciences, specifically thirteen held degrees in Psychology, four in Education Sciences, three in Sociology, two in Social Services and one in Anthropology. Moreover, nine adult educators held education degrees in teaching.

There were few adult educators who in their initial qualification had studied subjects linked with adult education. This was the case of some adult educators with higher education degrees in Education Sciences, as was referred to by one interviewee:

I, during my basic degree in Education Sciences, had attended an adult education course.... (Inês)

However, the initial qualification of the majority of the adult educators didn't include the subject of adult education. So, how did adult educators learn to do this job? 
The adult educators interviewed have learned through several ways. Experience was the common element to all learning pathways. Experience had a crucial importance in the learning process, as there were only a few interviewees who, in the course of their initial qualification, had contact with adult education. As outlined by one interviewee,

[I learned] with work, I had nobody who has taught me. I didn't have too much guidance from people, from colleagues. I have learned to do this work alone, daily, with day-to-day experience, always improving, each time more, but it is continuous learning. (Alzira)

Adult educators learned a new professional activity in action, while they were performing the tasks and duties of the job. Experience and reflection about experience was one way of learning how to become an adult educator. The reinterpretation of experience by the individual can transform an experienced action into the appropriation of that action (Clénet, 2012), leading to learning.

Adult educators also learned through attending continuing education courses after they had started working in RPL. These continuing education courses were mostly provided by the national agency responsible for adult education, which at the time was called the National Agency for Qualification and was later called the National Agency for Qualification and Vocational Teaching. As was referred to by one interviewee,

I started working in early November and I remember that during that year I had received training from the National Agency for Adult Education and Training. Over several days I learned everything about referential competences, balance methodologies, jury sessions and about how jury sessions should take place. All of this really helped me. (Carolina)

The learning process of how to exercise this professional activity was also carried out based on observation, talking with colleagues and sharing information, working processes and procedures. As was told by one interviewee,

When I first came here I learned as much as I could about all the activities, I had colleagues who supported me and also taught me some of their practical skills. I also observed some of my colleagues' sessions. The whole thing is actually quite intuitive. (Roberta)

Adult educators interviewed had several learning pathways. Experience was the common element to all learning processes. It was through the performing of the professional activity, therefore in action, that all adult educators had learned their new professional activity. Experience had a fundamental importance in the learning process, since there were few adult educators who had contact with adult education in their initial qualification. Individuals can learn a lot through the action, and mainly through the analysis of the action (Pastré, 2007). The reflective and retrospective analysis about the action is a learning tool. The work analysis of a professional activity is a key moment in the building of meaning to the experiences of the individual. 
When the interviews were undertaken the majority of adult educators were experiencing a time of big uncertainty. Due to a change of the government, adult educational policies had also changed. But professional uncertainty was a permanent situation for most adult educators because they had temporary employment contracts.

One strategy used by adult educators to cope with uncertainty of the labour market was to diversify their knowledge and competences. Some adult educators achieved vocational or higher education degrees in several subjects, always related to what they thought would offer more employment opportunities in the future. As was mentioned by two interviewees,

Since I have finished my licenciate degree, my idea was always to diversify my knowledge, having in mind the context in which we are living, in other words to have a wider range of possibilities at the professional level. (Rute)

Professionally, an area I also like is training management, and so I also want to invest in some training courses, in qualification in this field, because Education Science [that is my area of initial qualification] is not an area with much employability.... (Inês)

Some adult educators had chosen to improve their qualifications in their higher education degree area with the aim to get a job in this field in the future. As was referred to by an interviewee,

Just now my professional pathway has met adult education due to an opportunity (...) because there was a time when I lived in a situation of unemployment. During this time I had applied here, in this foundation, and there was a vacancy in the New Opportunities Centre. That's how I got here. (Tânia)

Regarding her continuing education, Tânia added,

I have not invested in the area of adult education. Currently I'm attending a masters' programme in the field of Community Psychology. (...) I'm not investing in technical, practical and theoretical terms in adult education and I do not think I will do it. (...) my initial qualification is the clinical area [Clinical Psychology]. (Tânia)

For these professionals, adult education was only a deviation in their professional pathway, often done to escape unemployment. These adult educators objective is to find a job in their higher education degree field, giving continuity to the investment made in the area of their initial qualification.

\section{FINAL REMARKS}

Following the changes that have happened in adult education, there were adult educators working in this field with professional pathways marked by discontinuity 
and employment instability. Social actors engaged in adult education were hostages of the changes in policies in this field.

With the emergence of new educational practices in adult education as was the case of RPL, there were adult educators who started to work without previous experience and most of them without knowledge and professional competences in this area. The data show us that these adult educators had a variety of initial qualification, and the only common point was the possession of a higher education degree (licenciate degree). Since some adult educators had initial qualification unrelated to adult education, they had learned in several ways, such as learning through experience, i.e., learning by doing, attending continuing education courses, seeing experienced peers working and sharing experiences with colleagues. We can say that adult educators had learned through eco-learning, hetero-learning (Pineau, 2009) and experiential learning, with direct and reflected contact with the learning situations (Josso, 1991).

Another important point to highlight is that, initially, learning dynamics demonstrated by adult educators promoted the acquisition of skills and competences about adult education. However, during their daily working life some adult educators had attended continuing education in some fields that they considered important to strengthen their employment competences, even in areas not related to adult education. They showed adjusted behaviour to cope with the flexibility of the labour market.

Concerning the ways of learning of adult educators and the instability of their working conditions, some questions can be raised. Insofar adult educators do not have an initial qualification in adult education, to what extent would it be important they have it and how does it could be structured? Regarding this issue, Guimarães (2016) pointed out that currently there are no specific formal education pathways directed to adult educators at the level of the initial qualification. A second question is related to continuing education in adult education. Since there is not too much continuing education, would it be pertinent to invest in this way of learning? Should continuing education be organised at national level or should it be structured and implemented by the different actors working in this field, adapting the contents of programmes to their unique work contexts? The lack of continuity of adult education policies in Portugal and the uncertainty of the labour market also leads to some questions regarding the way how adult educators are facing their work and themselves: What effects do the uncertain professional contexts have on the ways adult educators face their work? What are the implications of the instability of work contexts on their professional identity? It is important to note that the instability of working conditions experienced by adult educators can lead them to a process of disinvestment both in terms of attending continuing education programmes and in terms of the involvement with their professional activity (Paulos, 2015). Reflecting on these questions and a subsequent attempt to respond them may contribute to having adult educators better prepared to work in times characterised by instability and uncertainty. 


\section{REFERENCES}

Alheit, P., \& Dausien, B. (2006). Processo de formação e aprendizagens ao longo da vida [Training process and lifelong learning]. Educação e Pesquisa, 32(1), 177-197.

Barbier, J.-M. (2009). Voies pour la recherche en formation. Éducation et didactique, 3(3), 119-130. Retrieved September 24, 2015, from http://educationdidactique.revues.org/588

Bardin, L. (1995). Análise de conteúdo [Content analysis]. Lisboa: Edições 70.

Bauman, Z. (2001). Modernidade líquida [Liquid modernity]. Rio de Janeiro: Jorge Zahar Editor.

Bondía, J. L. (2002). Notas sobre a experiência e o saber de experiência [Notes about experience and knowledge experience]. Revista Brasileira de Educação, 19, 20-28.

Canário, R. (2008). Educação de adultos: Um campo e uma problemática [Adult education: A field and a problematic]. Lisboa: EDUCA.

Castro, R. V., Guimarães, P., \& Sancho, A. V. (2007). Mutações no campo da educação de adultos. Sobre os caminhos da formação dos educadores [Mutations in the field of adult education: On the ways of educators training]. Educar, 29, 63-81.

Cavaco, C. (2009). Experiência e formação experiencial: a especificidade dos adquiridos experienciais [Experience and experiential learning: The specificity of prior learning]. Educação Unisinos, 13(3), 220-227.

Charlier, E., Roussel, J. F., \& Boucenna, S. (2013). L'apprentissage par l'expérience: une thématique centrale dans la formation d'adultes. In E. Charlier, J.-F. Roussel, \& S. Boucenna (Dirs.), Expériences des adultes et professionnalités des formateurs (pp. 9-17). Bruxelles: De Boeck.

Charlot, B. (2000). Da relação com o saber: Elementos para uma teoria [The relationship to knowledge: Elements for a theory]. Porto Alegre: Artmed Editora.

Clénet, J. (2012). Se former et se professionaliser. Le point de vue du sujet. In D. Demazière, P. Roquet, \& R. Wittorski (Coords.), La professionnalisation mise en objet (pp. 153-172). Paris: L'Harmattan.

Creswell, J. W. (2007). Qualitative inquiry and research design: Choosing among five approaches. Thousand Oaks, CA: Sage Publications.

Delory-Momberger, C. (2012). Abordagens metodológicas na pesquisa biográfica [Methodological approaches in biographical research]. Revista Brasileira de Educação, 17(51), 523-536.

Demazière, D. (2008). L'entretien biographique comme interaction négociations, contre-interprétations, ajustements de sens. Langage \& Société, 1(123), 15-35.

Dominicé, P. (1991). La formation expérientielle: un concept importé pour penser la formation. In B. Courtois \& G. Pineau (Coords.), La formation expérientielle des adultes (pp. 53-58). Paris: La Documentation Française.

Dominicé, P. (2006). A formação de adultos confrontada pelo imperativo biográfico [Adult training confronted by the biographical imperative]. Educação e Pesquisa, 32(2), 345-357.

Filander, K. (2005). Experts in uncertainty: Making cultural analysis of identities in adult education. In A. Bron, E. Kurantowicz, H. S. Olesen, \& L. West (Orgs.), 'Old' and 'new' worlds of adult learning (pp. 56-69). Wroclaw: Wydawnictwo Naukowe.

Guimarães, P. (2016). Ocupações da educação de adultos e desafios à profissionalização: tarefas e atividades desenvolvidas em contexto de trabalho [Occupations of adult education and challenges to professionalization: Tasks and activities developed in work context]. Revista de Estudos Curriculares, $7(2), 57-81$.

Jarvis, P. (2006). Towards a comprehensive theory of human learning. London: Routledge.

Josso, M.-C. (1991). L'expérience formatrice: un concept en construction. In B. Courtois \& G. Pineau (Coords.), La formation expérientielle des adultes (pp. 191-199). Paris: La Documentation Française.

Josso, M.-C. (2002). Experiências de vida e formação [Life experiences and training]. Lisboa: EDUCA.

Josso, M.-C. (2008). Formação de adultos: Aprender a viver e a gerir as mudanças [Adult training: Learning to live and to manage changes]. In R. Canário \& B. Cabrito (Orgs.), Educação e formação de adultos: mutações e convergências (pp. 115-125). Lisboa: EDUCA.

Kolb, D. A. (1984). Experiential learning: Experience as the source of learning and development. Englewood Cliffs, NJ: Prentice Hall. 


\section{PAULOS}

Lietard, B. (2007). Apologie critique de la formation expérientielle. Vie Sociale, 4, 11-20. Retrieved December 2, 2015, from https://www.cairn.info/revue-vie-sociale-2007-4-page-11.htm

Lima, L. (2008). A educação de adultos em Portugal (1974-2004): Entre as lógicas da educação popular e da gestão de recursos humanos [Adult education in Portugal (1974-2004): Between the logic of popular education and the human resource management]. In R. Canário \& B. Cabrito (Orgs.), Educação e formação de adultos. Mutações e convergências (pp. 31-60). Lisboa: EDUCA.

Loureiro, A. P. F. (2012). "Novos" territórios e agentes educativos em sociologia da educação: o caso da educação de adultos ["New" territories and educational agents in sociology of education: The case of adult education]. Revista Lusófona de Educação, 20, 123-139.

Méda, D. (1999). O trabalho. Um valor em vias de extinção [The work. A value endangered]. Lisboa: Fim de Século.

Mezirow, J. (1990). How critical reflection triggers transformative learning. In J. Mezirow \& Associates (Orgs.), Fostering critical reflection in adulthood: A guide to transformative and emancipatory learning (pp. 1-20). San Francisco, CA: Jossey-Bass.

Mezirow, J. (2000). Learning to think like an adult: Core concepts of transformation theory. In J. Mezirow \& Associates (Orgs.), Learning as transformation: Critical perspectives on a theory in progress (pp. 3-33). San Francisco, CA: Jossey-Bass.

Monbaron, J. (2009). Exister dans le labyrinthe de nos parcours: mise en scène de la vie adulte. In J.-P. Boutinet \& P. Dominicé (Orgs.), Où sont passés les adultes? Routes et déroutes d'un âge de la vie (pp. 85-102). Paris: Téraèdre.

Pastré, P. (2007). Analyse du travail et formation. Recherches en Education, 4, 23-28. Retrieved December 4, 2015, from http://www.recherches-en-education.net/IMG/pdf/REE-no4.pdf

Paulos, C. (2015). Qualification of adult educators in Europe: Insights from the Portuguese case. International Journal for Research in Vocational Education and Training, 2(1), 25-38.

Pineau, G. (1991). Formation expérientielle et théorie tripolaire de la formation. In B. Courtois \& G. Pineau (Coords.), La formation expérientielle des adultes (pp. 29-40). Paris: La Documentation Française.

Pineau, G. (2009). L'autoformation dans le cours de la vie: entre l'hétéro et l'écoformation. Education Permanente, 180, 141-154.

Pineau, G., \& Le Grand, J.-L. (1993). Les histoires de vie. Paris: Presses Universitaires de France.

Robin, J.-Y. (2009). Les parcours professionnels: des indicateurs encore pertinents pour penser la vie adulte? In J.-P. Boutinet \& P. Dominicé (Orgs.), Où sont passés les adultes? Routes et déroutes d'un âge de la vie (pp. 123-144). Paris: Téraèdre.

Rothes, L. A. (2004). A formação de educadores de adultos em Portugal: Trajectos e tendências [The training of adult educators in Portugal: Pathways and tendencies]. In L. C. Lima (Org.), Educação de adultos - Forum III (pp. 61-85). Braga: Universidade do Minho.

Villers, G. (1991). L'expérience en formation d'adultes. In B. Courtois \& G. Pineau (Coords.), La formation expérientielle des adultes (pp. 13-20). Paris: La Documentation Française.

XXI Governo. (2016). Programa nacional de reformas 2016 - mais crescimento, melhor emprego, maior igualdade - qualificar os portugueses [National program of reforms 2016 - more growth, better employment, greater equality - qualify the Portuguese]. Retrieved January 2, 2017, from http://www.portugal.gov.pt/media/19012677/20160418-mtsss-pnr-qualificacao.pdf

Zeitler, A., Guérin, J., \& Barbier, J.-M. (2012). La construction de l'expérience. Recherche et formation, 70, 9-14. Retrieved September 22, 2015, from http://www.cairn.info/revue-recherche-et-formation2012-2-page-9.htm

\section{Catarina Paulo}

University of Lisbon

Portugal 